\title{
EVIDENCE-BASED PRACTICE IN FORENSIC MEDICINE
}

Citation for published version (APA):

Meilia, P. (2022). EVIDENCE-BASED PRACTICE IN FORENSIC MEDICINE: From INFERENCE to PERFORMance. [Doctoral Thesis, Maastricht University]. Maastricht University. https://doi.org/10.26481/dis.20220124pm

Document status and date:

Published: 01/01/2022

DOI:

10.26481/dis.20220124pm

Document Version:

Publisher's PDF, also known as Version of record

\section{Please check the document version of this publication:}

- A submitted manuscript is the version of the article upon submission and before peer-review. There can be important differences between the submitted version and the official published version of record.

People interested in the research are advised to contact the author for the final version of the publication, or visit the DOI to the publisher's website.

- The final author version and the galley proof are versions of the publication after peer review.

- The final published version features the final layout of the paper including the volume, issue and page numbers.

Link to publication

\footnotetext{
General rights rights.

- You may freely distribute the URL identifying the publication in the public portal. please follow below link for the End User Agreement:

www.umlib.nl/taverne-license

Take down policy

If you believe that this document breaches copyright please contact us at:

repository@maastrichtuniversity.nl

providing details and we will investigate your claim.
}

Copyright and moral rights for the publications made accessible in the public portal are retained by the authors and/or other copyright owners and it is a condition of accessing publications that users recognise and abide by the legal requirements associated with these

- Users may download and print one copy of any publication from the public portal for the purpose of private study or research.

- You may not further distribute the material or use it for any profit-making activity or commercial gain

If the publication is distributed under the terms of Article $25 \mathrm{fa}$ of the Dutch Copyright Act, indicated by the "Taverne" license above, 


\section{SUMMARY}

The process of expert opinion formulation in forensic medicine is typically not based on evidence-based practice (EBP) principles. The result is expert opinions that are less scientifically reliable and thereby more easily contested. This shortcoming can lead to sporadic or idiosyncratic distribution of justice by legal decision makers who rely on expert opinions, which in turn increases the risk of erroneous (and unjust) legal decisions. For these reasons, a method and guide for the formulation and reporting of forensic medical expert opinions is needed to produce expert opinions that are more reliable and less contestable.

The first part of this thesis aims at setting the stage for the discussion about EBP in forensic medicine. Chapter 2 contains a review of the diversity in taxonomy, definitions, scope, and roles in forensic medicine and their implications for evidence-based practice. The terms forensic medicine, legal medicine, medical jurisprudence, medico-legal services, forensic pathology, and clinical forensic medicine are used with mixed interpretations in different jurisdictions resulting in different systems and practices. The methods used by forensic medical practitioners are often not evidence-based, or based on standardized methods, and vary greatly between experts and centers. There are also no universally accepted guidelines for preparing a standard and admissible forensic pathology report. The lack of a uniform system in forensic medicine creates barriers in assessing the development and performance of forensic medicine as a distinct discipline.

The second part of this thesis (Chapter 3) consists of two sections. The first section comprises of a review of causal inference in forensic medicine. At the present time, there exists no universally applied systematic methodology for formulating and assessing causality in forensic medical expert opinions. Current approaches to causation in forensic medicine can be generally described as either intuitive or probabilistic, with the former more experience-based and the latter more consistent with EBP principles. Based on the review from section one, in section two a new unified model to evaluate medicolegal causality is proposed, dubbed the INFERENCE (INtegration of Forensic Epidemiology and the Rigorous Evaluation of Causation Elements) approach. The purpose of the model is to aid experts in formulating EBP-based causation opinions in medicolegal cases. The model development process, which is based on a review of current approaches to causal analysis, is described, as well as when and how to use the model.

In the third part of the thesis (Chapter 4) is a discussion of a new set of recommendations on reporting in forensic pathology named the PERFORM-P (Principles of Evidence-based Reporting in FORensic Medicine-Pathology version). The development of PERFORM-P through a Delphi consensus process with international participants is described in detail. The goal of the PERFORM-P is to provide forensic medical practitioners with recommendations on how to produce forensic pathology reports that are consistent with EBP principles but are still adaptable to local regulations and customs. PERFORM-P consists of a list of 61 items to be included in a forensic pathology 
report, which is accompanied by its Explanation and Elaboration (E\&E) document. The PERFORM-P takes the form of recommendations for necessary elements to include in a forensic pathology report and can be applied to a wide range of matters requiring forensic pathological analysis, which are demonstrably accepted by forensic pathologists from a representative selection of jurisdictions and medico-legal systems.

In Chapter 5, an outbreak investigation is used to illustrate the application of the INFERENCE approach to produce an evidence-based forensic medical expert opinion. This chapter presents the use of the INFERENCE causation approach in a medical malpractice litigation case. A unique aspect of the case is that it is a part of a healthcare-associated infection (HAI) outbreak allegedly caused by infection prevention and control (IPAC) violations. Outbreaks are usually investigated using epidemiologic methods. Because the INFERENCE approach is rooted in forensic epidemiology, it is suitable to be used in the causal analysis of this case.

In the last part of the thesis, a discussion on the use and value of evidence-based practice in forensic medicine is provided. Chapter 6 discusses the pros and cons of the results obtained in the preceding chapters and the overall strengths and limitations of this thesis. In also contains a general conclusion of the whole thesis. Finally, Chapter 7 presents the impact of this thesis, as a translation of the results of this thesis from knowledge to practice, and beyond. 


\section{NEDERLANDSE SAMENVATTING}

Deskundigen-advies in de forensische geneeskunde is doorgaans nog niet gebaseerd op de beginselen van de evidence-based practice (EBP). Dit proefschrift probeert hier verandering in te brengen. Als deskundigen rapporten wetenschappelijk minder betrouwbaar of transparant zijn, zijn ze gemakkelijker te betwisten en is de kans op foutieve (en mogelijk onrechtvaardige) juridische uitspraak groter. Richtlijnen voor het formuleren en rapporteren van forensisch geneeskundige expertadviezen kunnen hiervoor een oplossing zijn.

Het eerste deel van dit proefschrift is bedoeld om de basis te leggen voor de discussie over EBP in de forensische geneeskunde. Hoofdstuk 2 bevat een overzicht van de diversiteit in taxonomie, definities, reikwijdte en rollen in de forensische geneeskunde en hun implicaties voor EBP. De termen forensische geneeskunde, juridische geneeskunde, medische jurisprudentie, medisch-juridische diensten, forensische pathologie en klinische forensische geneeskunde worden gebruikt met verschillende interpretaties in verschillende rechtsgebieden. Er zijn ook geen algemeen aanvaarde richtlijnen voor het opstellen van een standaard en toelaatbaar forensisch pathologierapport.

Het tweede deel van dit proefschrift (Hoofdstuk 3) bestaat uit twee delen. Het eerste deel omvat een overzicht van de verschillende causale redeneringen die in de forensische geneeskunde gebruikt worden. Er bestaat op dit moment nog geen universeel toegepaste systematische methodologie voor het formuleren en beoordelen van causaliteit in forensisch geneeskundige expertadviezen. De huidige benaderingen voor onderzoek naar oorzaak-gevolg relaties in de forensische geneeskunde kunnen worden onderverdeeld in "intuittief" en "probabilistisch", waarbij de eerste meer op ervaring is gebaseerd en de laatste meer in overeenstemming met de EBP-principes.

In het tweede deel van Hoofdstuk 3, wordt een nieuw model voorgesteld om causaliteit te evalueren in de medisch-forensische context, genaamd de INFERENCE (INtegration of Forensic Epidemiology and the Rigorous Evaluation of Causation Elements) benadering. Het doel van dit model is om experts te ondersteunen bij het formuleren van op EBP gebaseerde causaliteitsadviezen in de medisch-juridische praktijk.

In het derde deel van het proefschrift (Hoofdstuk 4) wordt een nieuwe "reporting guideline" gepresenteerd voor advisering binnen de forensische pathologie genaamd de PERFORM-P (Principles of Evidence-based Reporting in FORensic Medicine-Pathology version). De ontwikkeling van PERFORM-P via een Delphi-consensusproces met internationale deelnemers wordt in detail beschreven. PERFORM-P bestaat uit een lijst van 61 items die moeten worden opgenomen in een forensisch pathologierapport.

In Hoofdstuk 5 wordt een uitbraakonderzoek gebruikt om de toepassing van de INFERENCE-benadering te illustreren. Het gaat hier om een uitbraak van zorg gerelateerde infecties (healthcare-associated infections/HAIs) dat mogelijk veroorzaakt is door schendingen van het infectiepreventie en -bestrijding (IPAC) beleid ter plaatse. 
In het laatste deel van het proefschrift wordt een discussie gegeven over het gebruik en de waarde van EBP in de forensische geneeskunde. Hoofdstuk 6 bespreekt de voor-en nadelen van de resultaten die in de voorgaande hoofdstukken zijn verkregen en de algemene sterke punten en beperkingen van dit proefschrift. Het bevat ook een algemene conclusie van het hele proefschrift. Ten slotte presenteert Hoofdstuk 7 de mogelijke maatschappelijke impact van dit proefschrift, als een vertaling van de resultaten van dit proefschrift van kennis naar de klinische praktijk. 